Relatlve risk $95 \%$ confidence intercal of breast cancer after term birth calculated from 422 women with breast cancer (cases) and 4.7 controls by age group

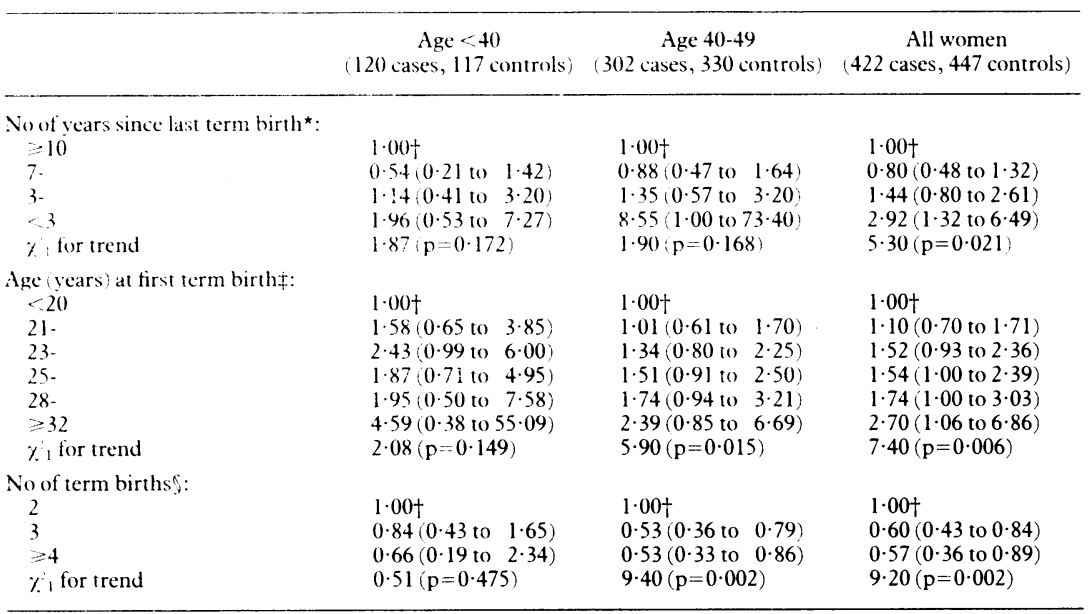

*Adjusted for age (two year intervals), age at first term birth, and parity.

tReference value for calculating relative risk.

$\neq$ Adjusted for age ( $t$ wo year intervals), years since last term birth, and parity.

$\checkmark$ Adiusted for age (two year intervals), years since last term birth, and age at first term birth.

Bruzzi et al reported a similar relative risk $(2 \cdot 66 ; 95 \%$ confidence interval 1.31 to $5 \cdot 39)$ to our own $(2 \cdot 92 ; 1.32$ to 6.49$)$ during the three years after the last full term pregnancy. ${ }^{3}$ They did not, however, provide data on the risk during the first year after such a pregnancy or details of the adjustments for age.

We found a significantly increased risk with decreasing interval since last term birth when adjustment for age was within five or two year bands but not when there was no adjustment for age. Although confidence intervals were wide, much of this risk occurred during the first year after the birth $(20.5 ; 2.57$ to 163.53$)$; the risk during the second and third years was raised only slightly $(1.37 ; 0.71$ to 2.66$)$. This finding might be attributable partly to the underrepresentation among the controls of women who had given birth within the previous year. Possibly women with new babies delay going into hospital for elective procedures; this is supported by data from our original matched study, which included nulliparous and primiparous women. Fewer controls (four) had had a full term pregnancy within the year before admission than was estimated from the national birth rate adjusted for age (nine) whereas 25 women with breast cancer had had such a pregnancy.

In conclusion, our results suggest that a modest, transient increase in the risk of breast cancer is associated with full term pregnancy, although the results may have been influenced by bias in the control group. Such a bias could also have affected the results of Bruzzi et al. ${ }^{3}$

1 Miller AB, Bulbrook RD. The epidemiology and etiology of breast cancer N Engl f Med 1980;303:1246-8.

Miller AB, Bulbrook RD. UICC multidisciplinary project on breast cancer: the epidemiology, etiology and prevention of breast cancer. Int $\mathcal{f}$ Cancer 1986;37:173-7

3 Bruzzi P, Negri E, La Vecchia C, et al. Short term increase in risk of breast cancer after full term pregnancy. Br Med $\mathcal{O}$ 1988;297:1096-8.

4 Meara J, McPherson K, Roberts M, Jones- L, Vessey M. Alcohol, cigarette smoking and breast cancer. Br $f$ Cancer 1989;60:70-3.

5 Office of Population Censuses and Surveys. Birth statistics. London: HMSO, 1985. (Series FM1.)

(Accepted 16 November 1989)

\title{
Proliferative retinopathy and nephropathy at presentation in young insulin dependent diabetics
}

\section{James A O'Hare}

Department of Medicine,

\section{Limerick Regional}

Hospital, Dooradoyle,

Limerick, Republic of

Ireland

James A O'Hare, FRCPI,

consultant endocrinologist

BrMed J 1990;300:579-80
I report the occurrence of proliferative diabetic retinopathy as the presenting symptom of type I diabetes in two young patients who also had polyneuropathy and early nephropathy. Such a presentation is extremely rare.

\section{Case reports}

Case 1-A 23 year old woman who had had polyuria for three months presented to her optician with blurring of vision. She had neovascularisation of the left optic disc and haemorrhages and exudates typical of diabetic retinopathy affecting both eyes. Her visual acuity was reduced to $6 / 18$ in the right eye and $6 / 12$ in the left eye. Fluorescein angiography showed extensive vascular exudation in both retinas, and she was given argon laser treatment. She weighed $52 \mathrm{~kg}$ and had not lost weight recently. She had a blood glucose

Characteristics of two patients presenting with proliferative diabetic retinopathy

\begin{tabular}{lcc} 
& Case 1 & Case 2 \\
\hline $\begin{array}{l}\text { Islet cell antibody } \\
\begin{array}{c}\text { Serum C peptide after stimulation } \\
\text { with glucagon (pmol/1)* }\end{array}\end{array}$ & Positive & Negative \\
$\begin{array}{c}\text { Daily insulin requirement } \\
\text { (units/kg body weight) }\end{array}$ & $<77$ & 520 \\
Tissue type & $0 \cdot 81$ & $0 \cdot 74$ \\
& HLA-A2, A11, B8, Bw55, DR3, DR4 & HLA-A1, A29, B8, B44, DR3, DR4
\end{tabular}

$\star$ Normal $>1000 \mathrm{pmol} / \mathrm{l}$ concentration of $18 \mathrm{nmol} / \mathrm{l}$, ketonuria, and a blood pressure of $124 / 80 \mathrm{~mm} \mathrm{Hg}$. Her sense of vibration and light touch in her feet was diminished, and deep tendon reflexes in her ankles were absent. She required 42 units of insulin daily in a conventional regimen of two injections, and her diabetes was easy to stabilise. Her glycated haemoglobin concentration was $15 \%$ (normal $5 \cdot 3-7 \cdot 2 \%$ ), and urinary excretion of protein after her diabetes had been stabilised was $120 \mathrm{mg} / 24 \mathrm{~h}$ (normal $<80 \mathrm{mg} / 24 \mathrm{~h}$ ). Special investigations showed typical type I diabetes (table).

Case 2-A 29 year old white man presented with a one month history of blurring of vision and a two month history of nocturia. He had a blood glucose concentration of $22 \mathrm{mmol} / \mathrm{l}$ and trace ketonuria. $\mathrm{He}$ weighed $65 \mathrm{~kg}$, having weighed $102 \mathrm{~kg} 10$ years previously. His blood pressure was $140 / 108 \mathrm{~mm} \mathrm{Hg}$, and examination of the cardiovascular system showed no abnormalities. Perception of vibration and temperature in his toes and the deep tendon reflexes in his ankles were diminished. His visual acuity was $6 / 12$ in the right eye and $6 / 6$ in the left. There was neovascularisation of both retinas and of the disc in the right eye with typical features of background diabetic retinopathy. Extensive laser treatment was given bilaterally. Visual acuity deteriorated, and he developed vitreous haemorrhages. His glycated haemoglobin concentration was $16 \cdot 5 \%$. An overnight (first morning) sample of urine had an albumin concentration of $55 \mathrm{mmol} / \mathrm{l}$ (normal $<20 \mathrm{mmol} / \mathrm{l}$ ). His diabetes was stabilised with $\mathbf{4 8}$ units of insulin given as two injections daily (table).

\section{Comment}

Both patients had proliferative diabetic retinopathy, diabetic polyneuropathy, and early nephropathy. Proliferative diabetic retinopathy in type I diabetes rarely develops until the diabetes has been present for 
10 years, and a large scale study did not find any case in the first five years of the disease.' There have been a few reports of proliferative retinopathy developing at an early stage of type I diabetes,' and proliferative retinopathy is occasionally seen as a presenting feature of type II diabetes, usually in patients aged 40 or older. ${ }^{3}$ In case 1 the patient had typical type I diabetes with islet cell antibodies and no residual $\beta$ cell function. The other patient was less typical of patients with type I diabetes as he had residual $\beta$ cell function and had been obese some years previously. Both patients, however, had the HLA-DR tissue type typical of type I diabetes. ${ }^{+}$ It has been suggested that this predisposes to proliferative diabetic retinopathy, though a recent study could not confirm this.

As duration of diabetes is so powerful a predictor of retinopathy, both patients had probably had undetected diabetes for many years. They may also have had some other underlying factor facilitating the rapid development of their complications.'

I thank Mr Ray Niland, Mr Brendan Young, and Dr Richard O'Regan for managing the ophthalmological aspect of these cases, and Miss Ann Donnellan for preparing the manuscript.

1 Klein R, Klein BEK, Moss SE, Davis MD, DeMets DL. The Wisconsin epidemiologic study of diabetic retinopathy. Arch Ophthalmol 1984;102: 520-6

2 Cove DH, Hill RD. Severe retinopathy at presentation of insulin dependent diabetes mellitus. Practical Diabetes 1986:3:218.

3 Barnes AJ, Kohner EM, Johnston DG, Alberti KGMM. Severe retinopathy and mild carbohydrate intolerance: possible role of insulin deficiency and elevated circulating growth hormone. Lancet 1985 ; : 1 1465-8.

4 Kahn CR. Pathophysiology of diabetes mellitus: an overview. In: Marble A, Krall LP, Bradley RF, Christlieb AR, Soeldner AJ, eds. Joslin's diabetes mellitus. Philadelphia: Lea and Febinger, 1982:43-51.

5 Groop LC, Teir S, Koskimies S, et al. Risk factors and markers associated with proliferative retinopathy in patients with insulin dependent diabetes. Diabetes 1986;35:1397-403.

(Accepted 29 November 1989)

\section{Public Health \\ Department, Regional Hospital of Metz, 57038 Metz, Cedex 1 , France \\ J F Viel, MD, research epidemiologist}

\section{Institut National de la} Santé et de la Recherche Médicale, 94807 Villejuif Cedex, France

S T Richardson, PHD, research epidemiologist

Correspondence and requests for reprints to: Dr Viel.

Br.Med f 1990;300:580-1

\section{Childhood leukaemia around the La Hague nuclear waste reprocessing plant}

\section{J F Viel, S T Richardson}

The incidence of childhood leukaemia around nuclear facilities has been a topic of much public attention and epidemiological investigation. ${ }^{2}$ The Sellafield and Dounreay nuclear waste reprocessing plants have been particularly investigated. ${ }^{34}$ A similar reprocessing plant has been operating in La Hague, Normandy, since 1966, several years after Sellafield was commissioned. The amount of radioactive effluent discharged has been much lower than that from Sellafield (the maximum annual discharge in the years to 1980 was $1592887 \mathrm{GBq}$ in 1975). The main radionuclides released are ruthenium-106, cerium-144 (up to 1980), caesium-137, and antimony-125. Discharges from Sellafield and La Hague differ in their isotope contents: Sellafield releases 10 to 160 times more ${ }^{137} \mathrm{C} s$ and La Hague four times more ${ }^{125} \mathrm{Sb} .{ }^{3}$ We report preliminary results on mortality from childhood leukaemia observed around the plant at La Hague.

\section{Methods and results}

Mortality for the periods $1968-78$ and $1979-86$ was provided by the Institute National de la Santé et de la Recherche Médicale, which records all the medical causes of deaths in France centrally. Three age groups were examined: $0-4$ years, 5-14 years, and $15-24$ years. We studied all electoral wards (around 10000 inhabitants) that had half or more of their area within a specified radius of the nuclear plant. Radiuses of $10 \mathrm{~km}, 20 \mathrm{~km}$, and $35 \mathrm{~km}$ were chosen before the analyses, so that 10 wards were included in the study. The expected numbers of cases of leukaemia (International Classification of Diseases (8th revision) codes 204-207; 9th revision codes 204-208) were estimated by applying the age specific rates for the département de la Manche for 1968-78 and 1979-86 to the 1975 and 1982 census populations of the predefined areas. Results were analysed by two tailed tests based on a Poisson distribution.

Only one death occurred in the area closest to the nuclear installation between 1968 and 1986 (table). Only one standardised mortality ratio was significantly different from one: the ratio for the age group 5-14 living $10-20 \mathrm{~km}$ from the plant during 1968-78 showed a decreased risk (observed number of deaths $=0$, expected=3.935). Because of the number of tests carried out (table) one of the tests would be expected to yield a significant result $(p<0.05)$ on the basis of chance.

The standardised mortality ratio for all the age groups, periods, and areas was $89 \%$ (observed number of deaths $=21$, expected $=23.6$ ); and was not significant ( $95 \%$ confidence interval 0.55 to $\mathrm{i} \cdot 36$ ). Furthermore, no significant trend between the two periods was found.

\section{Comment}

Assessing the risk of disease around a source of environmental pollution is subject to many statistical problems, including the selection of the boundaries of the area to be studied, the choice of a reference rate, and the use of the Poisson distribution. It is difficult to attempt any other kind of statistical analysis with the available data. A registry of all cases of leukaemia and their exact location needs to be established, especially as improvements in treating childhood leukaemia are being reflected in a falling mortality. The Commission d'Information de la Hague instigated a comprehensive

Mortality from leukaemia around La Hague nuclear reprocessing plant according to age, period of study, and distance from plant

\begin{tabular}{|c|c|c|c|c|c|c|c|c|c|}
\hline \multirow[b]{2}{*}{$\begin{array}{l}\text { Period of study } \\
\text { and distance } \\
\text { from plant }\end{array}$} & \multicolumn{3}{|c|}{ 0-4 Years } & \multicolumn{3}{|c|}{ 5-14 Years } & \multicolumn{3}{|c|}{ 15-24 Years } \\
\hline & $\begin{array}{c}\text { Observed } \\
\text { deaths }\end{array}$ & $\begin{array}{c}\text { Expected } \\
\text { deaths }\end{array}$ & $\begin{array}{l}\text { Standardised } \\
\text { mortality ratio } \\
(\%)\end{array}$ & $\begin{array}{c}\text { Observed } \\
\text { deaths }\end{array}$ & $\begin{array}{c}\text { Expected } \\
\text { deaths }\end{array}$ & $\begin{array}{l}\text { Standardised } \\
\text { mortality } \\
\text { ratio }(\%)\end{array}$ & $\begin{array}{c}\text { Observed } \\
\text { deaths }\end{array}$ & $\begin{array}{c}\text { Expected } \\
\text { deaths }\end{array}$ & $\begin{array}{l}\text { Standardised } \\
\text { mortality } \\
\text { ratio }(\%)\end{array}$ \\
\hline \multicolumn{10}{|l|}{ 1968-78: } \\
\hline$<10 \mathrm{~km}$ & 0 & $0 \cdot 143$ & 0 & 0 & $0 \cdot 340$ & 0 & 0 & $0 \cdot 136$ & 0 \\
\hline $10-<20 \mathrm{~km}$ & 2 & 1.831 & 109 & 0 & 3.935 & $0^{\star}$ & 5 & 2.002 & 250 \\
\hline \multirow{2}{*}{\multicolumn{10}{|c|}{ 1979-86: }} \\
\hline & & & & & & & & & \\
\hline$<10 \mathrm{~km}$ & 0 & 0.096 & 0 & 0 & $0 \cdot 220$ & 0 & 1 & $0 \cdot 214$ & 467 \\
\hline $10-<20 \mathrm{~km}$ & 2 & 0.986 & 203 & 2 & $2 \cdot 126$ & 94 & 1 & 2.579 & 38 \\
\hline $20-<35 \mathrm{~km}$ & 1 & 0.669 & 149 & 2 & 1.617 & 123 & 2 & 1.746 & 115 \\
\hline
\end{tabular}

${ }^{*} \mathrm{p}<0.05$ 